\title{
Autofluorescence and spectral-domain optical coherence tomography of optic disk melanocytoma
}

\author{
Autofluorescência e tomografia de coerência óptica de domínio espectral do melanocitoma do disco óptico
}

Ricardo luz leitão Guerra ${ }^{1}$, Eduardo Ferrari Marback², Igor Sandes Pessoa da Silva ${ }^{3}$, Otacílıo de Oliveira Maia Jr. ${ }^{3}$, Roberto Lorens Marback ${ }^{3}$

\section{ABSTRACT}

The authors report fundus autofluorescence (FAF) and spectral-domain optical coherence tomography (OCT) findings of two consecutive patients who presented with optic disk melanocytoma (ODM). A retrospective study was performed by reviewing medical records and ophthalmic imaging examinations. Optical coherence tomography findings were sloped and brightly reflective anterior tumor surface, adjacent retinal desorganization and abrupt posterior optical shadowing. Vitreous seeds were found in one patient. Fundus autofluorescence revealed outstanding hypoautofluorescence at the tumor area and isoautofluorescence at the remaining retina. Optical coherence tomography findings of the reported cases are consistent with those reported in the reviewed literature. Fundus autofluorescence has been used in the assessment of choroidal melanocytic tumors, but not yet in melanocytomas. We assume that this is the first report of these findings and believe that when its pattern has become clearly defined, fundus autofluorescence will be a useful tool to avoid misdiagnosis in suspicious cases and for follow-up.

Keyword: Melanoma/diagnosis; Optic nerve neoplasms/diagnosis; Tomography, optical coherence; Fluorescein angiography; Humans; Male; Female; Adult; Case reports

\section{RESUMO}

Os autores descrevem os achados do exame de autofluorescência do fundo de olho (AF) e da tomografia de coerência óptica (TCO) de domínio-espectralem dois pacientes consecutivos apresentando melanocitoma disco óptico (MDO) em um estudo retrospectivo, por revisão dos prontuários e exames oftalmológicos de imagem. Os achados no exame de tomografia de coerência óptica foram hiperrefletividade e elevação da superfície anterior da lesão, desorganização da retina adjacente, e, sombreamento óptico posterior. Sementes vítreas foram encontrados em um paciente. O exame de autofluorêscencia do fundo de olho revelou hipoautofluorescência marcante na área do tumor e isoautofluorescência nas demais áreas da retina. As características encontradas na tomografia de coerência óptica dos pacientes apresentados são consistentes com os achados relatados na literatura atual. A autofluorêscencia do fundo de olho tem sido utilizada na avaliação de tumores melanocíticos da coroide, mas ainda não em melanocitomas. Acreditamos que este seja a primeira descrição dos achados de autofluorêscencia do fundo de olho em pacientes com melanocitoma de disco ópticoe que, quando seu padrão de tornar-seclaramente definido, a autofluorêscencia do fundo de olho será uma ferramenta útil para evitar erros de diagnóstico em casos suspeitos.

Descritores: Melanoma/diagnóstico; Neoplasias do nervo óptico/diagnóstico; Tomografia de coerência óptica; Angiofluoresceinografia; Humanos; Masculino; Feminino; Adulto; Relato de casos

\section{INTRODUCTION}

Optic disk melanocytoma (ODM) is a relatively common and well-known benign intraocular tumor ${ }^{(1)}$. It can be defined as a melanocytic nevus variant located at the optic disk and histopathologically presents as uniform, deeply pigmented cells with melanosomes and after bleaching, small uniform nuclei with inconspicuous nucleoli and abundant cytoplasm(2).

ODM is usually diagnosed by ophthalmoscopic examination due to the characteristic appearance of the tumor $r^{(1,3,4)}$. Ancillary procedures, such as fundus photography, fluorescein angiography (FA), and optical coherence tomography (OCT), can help the diagnosis and are useful for follow-up evaluations ${ }^{(1)}$

Fundus autofluorescence (FAF) is a non-invasive examination based on the fluorescent appearance of lipofuscin when illuminated by an external light source ${ }^{(5)}$. Lipofuscin is a mixture of proteins, lipids, and small chromophores that accumulate in retinal pigment epithelium (RPE) as a result of incomplete or deficient photoreceptor outer segment degradation ${ }^{(6)}$. Depending on the intensity of the autofluorescence, a lesion may be described as isoautofluorescent, hypoautofluorescent, or hyperautofluorescent ${ }^{(5)}$.
FAF has been used in the assessment of choroidal melanocytic tumors but not yet in melanocytomas ${ }^{(3)}$. The aim of this paper is to describe the clinical features and FAF and OCT findings of two consecutive patients who presented with ODM.

\section{METHODS}

A retrospective study was performed by reviewing medical records of two consecutive patients diagnosed with ODM and referred to an ophthalmic oncology specialist at the Hospital Universitário Professor Edgard Santos, Salvador (BA), Brazil within a three-month period (June-September, 2012). Both patients had undergone ancillary procedures at the Retina and Vitreous service of the Hospital São Rafael (Fundação Monte-Tabor), Salvador (BA), Brazil.The study protocol was approved by the Institutional Ethics Review Board of the Hospital São Rafael-Fundação Monte-Tabor and conducted by the Retina and Vitreous Service at the same institution (CAAE: 14929313.4.0000.0048).

Ancillary procedures performed were color and red free retinography, FAF, FA and spectral-domain OCT. A Topcon TRC-50DX retinal camera and Optovue-RTVue 100 were used.
Submitted for publication: January 6, 2014

Accepted for publication: March 20, 2014

Study conducted at Vitreoretinal Service, Hospital São Rafael - Fundação Monte Tabor - Salvador, BA, Brazil.

Clínica de Olhos Leitão Guerra, Salvador, BA, Brazil.

Department of Ophthalmology, Universidade Federal da Bahia, (UFBA), Salvador, BA, Brazil.

${ }^{3}$ Department of Ophthalmology, Hospital São Rafael, Fundação Monte Tabor, Salvador, BA, Brazil.
Funding: No specific financial support was available for this study.

Disclosure of potential conflicts of interest: None of the authors have any potential conflicts of interest to disclose.

Corresponding author: Ricardo Leitão Guerra. Rua Catarina Paraguaçu, 8 - Salvador, BA - 40150 - 200 Brazil - E-mail: ricardo@leitaoguerra.com.br 
Demographics, clinical data, and ophthalmic imaging examination findings were described and compared with the actual relevant literature. The ophthalmological examination, ancillary procedures, and data collection were performed by the same ophthalmologist.

\section{RESULTS}

\section{CASE 1}

A 48-year-old female, dark-skinned, without comorbidities, was referred to an ophthalmic oncology specialist due to a pigmented intraocular tumor causing progressive vision loss in the right eye (OD). Best corrected visual acuity was counting fingers (CF) in OD and 20/25 in the left eye (OS). Biomicroscopy and tonometry were normal in both eyes (OU). Ophthalmoscopy presented as a black mass covering the optic disk and adjacent retina, including the fovea, with some vitreous seeding in the OD (Figure $1 \mathrm{~A}$ ). There were no significant findings in the OS.

FA presented as a hypofluorescent image with regular and well-defined outlines during the whole examination, matching to fluorescence blockage caused by tumor in the OD. There were no significant findings in the OS.

\section{CASE 2}

A 53-year-old male, dark-skinned, with systemic arterial hypertension was referred to an ophthalmic oncology specialist due to a pigmented intraocular tumor found in a routine examination. Best corrected visual acuity in OU was 20/20, and biomicroscopy and tonometry revealed no changes in OU. Ophthalmoscopy showed a black mass covering the optic disk and some adjacent retina, with massive vitreous seeding, preserving the macula in the OD (Figure $1 \mathrm{~B})$. There were no relevant findings in the OS. FA showed the same pattern as that described in case 1.

\section{SPECTRAL-Domain OCT and FAF}

Both cases presented similar OCT and FAF findings. Spectral-domain OCT showed an elevated hi-reflective line corresponding to the tumor surface, followed by a dense shadow pictured as an optically empty mass (Figures $2 \mathrm{~A}$ and B). Hi-reflective spots in the vitreous cavity anterior to the tumor and corresponding to vitreous seeding were found in case 2 (Figure 2 C).

FAF revealed an outstanding hypoautofluorescence. The remaining retina demonstrated isoautofluorescence (Figures $3 \mathrm{~A}$ and $\mathrm{B}$ ).

\section{DISCUSSION}

Despite the characteristic clinical appearance of melanocytoma, conditions such as primary or metastatic choroidal melanoma and combined hamartoma of the retina and RPE must first be ruled out ${ }^{(1,3,4)}$. Other differential diagnoses include choroidal nevus, RPE hyperplasia, and RPE adenoma ${ }^{(1,4)}$. Transformation of melanocytoma into malignant melanoma is extremely rare ${ }^{(6)}$.

OCT is a valuable tool for examining the retina and inner choroid architecture $^{(7)}$. OCT patterns and applications are well described in several choroidal and retinal tumors ${ }^{(4,7)}$. OCT findings in ODM include sloped and brightly reflective anterior tumor surface, adjacent retinal disorganization, and abrupt posterior optical shadowing ${ }^{(3)}$. Vitreous seeds can be found ${ }^{(4)}$. Both of the presented cases showed the characteristic features. Vitreous seeds were evident in one patient.

A leading cause of decreased visual acuity in ODM is related to retinal exudation ${ }^{(8)}$. Rarely, excessive tumor growth, involving the fovea, is the cause of vision loss ${ }^{(1)}$. OCT is useful in providing information about the adjacent retinal tissue in $\mathrm{ODMs}^{(4)}$. In case 1, OCT was valuable in delimitating the tumor extention and excluding other treatable conditions.

FAF has been previously used in the assessment of choroidal melanocytic tumors but not yet in melanocytomas ${ }^{(3)}$. In both described cases, FAF showed the same pattern: the tumor appears as an outstanding hypoautofluorescent lesion and the remaining retina was isoautofluorescent

In an OCT-pathologic correlation, Finger et al. showed a very similar OCT image ${ }^{(9)}$. Histopathologically, they found a thin layer of gliotic and disorganized retina covering the tumor surface ${ }^{(9)}$. We suppose that the absence of RPE over the tumor, and therefore lipofuscin, is associated with the highly pigmented mass blocking the posterior RPE, which can explain the outstanding hypoautofluorescence. Further studies are necessary to confirm these assumptions due to the great variability of the ODM presentations despite the small sample in this study.

FAF findings in ODM differential diagnoses, such as choroidal melanoma and choroidal nevus, have been previously described $(5,10,11)$. FAF is useful in documenting the presence of lipofuscin, a finding that represents an important criterion in differentiating small choroidal melanoma from benign choroidal nevus ${ }^{(5)}$. Choroidal melanomas have mild autofluorescent properties (granular appearance in 92\% of cases and nongranular appearance in $8 \%)^{(5)}$. Lately, a quantification method of digital autofluorescence was suggested for distinguishing nevi from melanomas with a sensitivity of 0.89 and specificity of $0.93^{(12)}$. The FAF patterns found in the presented cases can be helpful for diagnosing suspicious melanocytic lesions.

The authors were not able to find any descriptions of ODM FAF in the reviewed literature. Therefore, we assume that this is the first report of these findings and believe that when its pattern has been clearly defined, FAF will be a useful tool to avoid misdiagnosis in suspicious cases and for follow-up.
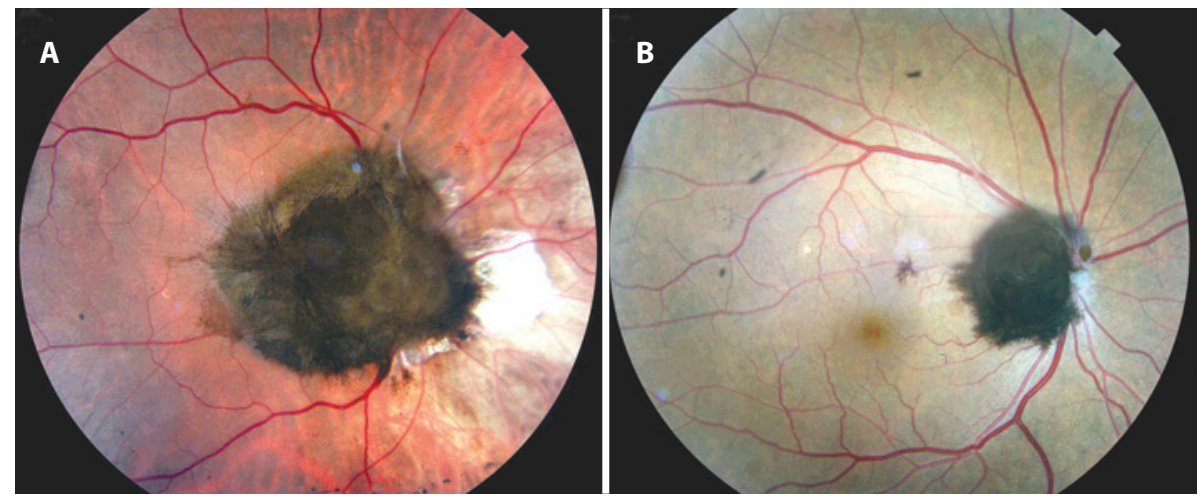

Figure 1. Clinical appearance of optic disk melanocytoma in the described patients. Case 1 (A). Case 2 (B). 

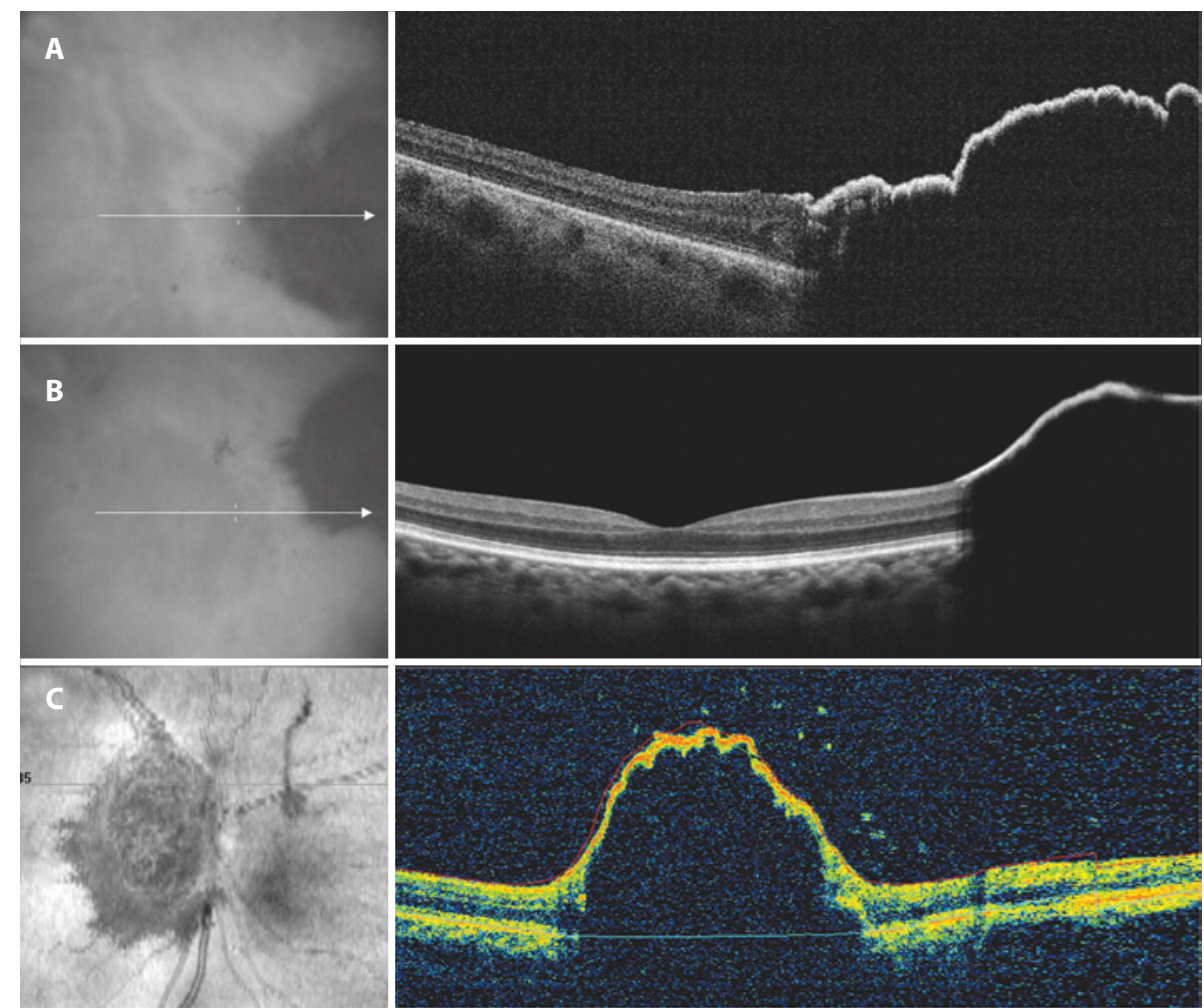

Figure 2. Spectral-domain OCT showing an elevated hi-reflective line corresponding to the tumor surface, followed by a dense shadow pictured as an optically empty mass (A and B). Hi-reflective spots in the vitreos cavity, antherior to the tumor, corresponding to vitreos seeding were found in case 2 (C).
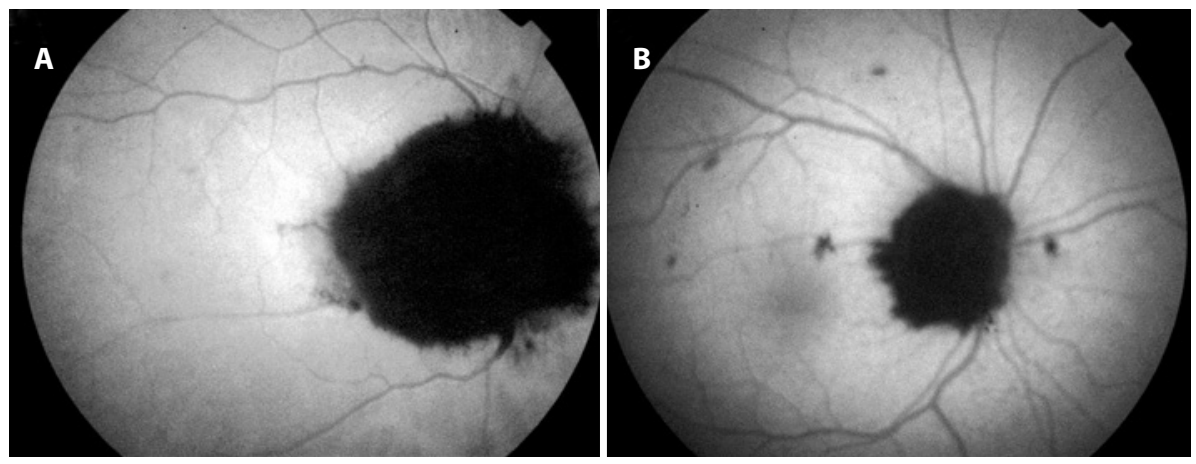

Figure 3. Outstanding hypoautofluorescence at the tumor area followed by isoautofluorescence at the remaining retina (A and B).

\section{REFERENCES}

1. Shields JA, Demirci H, Mashayekhi A, Eagle RC Jr, Shields CL. Melanocytoma of the optic disk: a review. Surv Ophthalmol. 2006;51(2):93-104.

2. Rao NA, Spencer WH. Optic nerve. In: Spencer WH. Ophthalmic pathology: an atlas and textbook. $4^{\text {th }}$ ed. Philadelphia: WB Saunders; 1996.

3. Esmaili DD, Mukai S, Jakobiec FA, Kim IK, Gragoudas ES. Ocular melanocytoma. Int Ophthalmol Clin. 2009;49(1):165-75

4. Shields CL, Perez B, Benavides R, Materin MA, Shields JA. Optical coherence tomography of optic disk melanocytoma in 15 cases. Retina. 2008;28(3):441-6.

5. Materin MA, Raducu R, Bianciotto C, Shields CL. Fundus autofluorescence and optical coherence tomography findings in choroidal melanocytic lesions. Middle East Afr J Ophthalmol. 2010;17(3):201-6.

6. Meyer D, Ge J, Blinder KJ, Sinard J, Xu S. Malignant transformation of an optic disk melanocytoma. Am J Ophthalmol. 1999;127(6):710-4.
7. Say EA, Shah SU, Ferenczy S, Shields CL. Optical coherence tomography of retinal and choroidal tumors. J Ophthalmol. 2012;2012:385058

8. Marback EF, Pereira FF, Galvão C, Maia Jr OO, Marback RL. Melanocitoma associado à membrana neovascular sub-retiniana. Rev Bras Oftalmol. 2009;68(4):237-40.

9. Finger PT, Natesh S, Milman T. Optical coherence tomography: pathology correlation of optic disk melanocytoma. Ophthalmology. 2010;117(1):114-9.

10. Lavinsky D, Belfort RN, Navajas E, Torres V, Martins MC, Belfort R Jr. Fundus autofluorescence of choroidal nevus and melanoma. Br J Ophthalmol. 2007;91(10):1299-302.

11. Shields CL, Bianciotto C, Pirondini C, Materin MA, Harmon SA, Shields JA. Autofluorescence of orange pigment overlying small choroidal melanoma. Retina. 2007;27(8): 1107-11.

12. Albertus DL, Schachar IH, Zahid S, Elner VM, Demirci H, Jayasundera T. Autofluorescence quantification of benign and malignant choroidal nevomelanocytic tumors. JAMA Ophthalmol. 2013;131(8):1004-8. 